Available online at http://bajas.edu.iq

https://doi.org/10.37077/25200860.2019.202 College of Agriculture, University of Basrah

Basrah Journal of

Agricultural

Sciences

E-ISSN: 2520-0860

ISSN 1814 - 5868 Basrah J. Agric. Sci., 32(2): 115-125, 2019

\title{
Effect of Adding Selenium with or Without Vitamin $E$ and Combination of them on some of Productive and Physiological Characteristics of Awassi Lambs
}

\author{
Emad A. Dhari ${ }^{1 *}$ \& Waleed Y. Kassim ${ }^{2}$ \\ ${ }^{1}$ Department of Animal Production - Directorate of Agriculture, Wasit, Iraq. \\ ${ }^{2}$ Department of Animal Production, College of Agriculture, University of Basrah, \\ Iraq
}

*Corresponding author E. mail: imad2881@yahoo.com

Received 17 Stem 2019; Accepted 14 October 2019; Available online 31 December, 2019

\begin{abstract}
The study was established to evaluate the effect of adding selenium with or without vitamin $\mathrm{E}$ on some of productive and physiological characteristics of Awassi male lambs. Sixteen lambs were selected after weaning with average weight of $24.30 \mathrm{~kg}$ and 3-4 months. All lambs fed 2\% of body weight with basal diet and $1 \mathrm{~kg}$ green alfalfa /Lamb/day. The lambs were randomly divided into 4 groups. Control group (no additives), Selenium group (0.4 mg selenium), Vitamin group (100 mg vitamin E) and selenium + vitamin E group $(0.4 \mathrm{mg}$ selenium + $100 \mathrm{mg}$ vitamin E) per kg dietary dry matter for 90 days. At the end of experiment, lamb performance and concentrations of Thyroxin T4, insulin and growth hormone were measured. The result showed that selenium and the combination of selenium + vitamin E treatments significantly increased $(\mathrm{p}<0.05)$ growth rates, final live body weight $42.20,41.75 \mathrm{~kg}$, respectively, and average daily gain 195, $191 \mathrm{~g}$ /day, respectively compared to other treatments. A significantly increase $(\mathrm{P}<0.05)$ in the concentrations of thyroxin hormone (T4) recorded in selenium + vitamin $\mathrm{E}$ treatment $18.20 \mathrm{ng} / \mathrm{ml}$ compared to selenium treatment and vitamin treatment. A significantly increase $(\mathrm{P}<0.05)$ in the concentrations of growth hormone of selenium treatment which recorded $9.279 \mathrm{ng} / \mathrm{ml}$ compared to vitamin treatment and control group. There is no difference in insulin hormone concentration between the groups. So we conclude that the addition of selenium with or without vitamin $\mathrm{E}$ to lamb diets achieved significant improvement in final body weight, daily weight gain, thyroxin and growth hormone.
\end{abstract}

Keywords: Awassi, lambs, selenium, vitamin E, hormone, performance.

\section{Introduction}

Mineral elements, especially trace ones play an important positive role in the health and efficiency of animal production and physiological processes, and are vital keys to the work of the internal organs of the body (Argüello, 2011). The ruminants depend on the plant content of the mineral element to meet their selenium requirements and that there is a correlation between their intake and levels of selenium in animal blood (Linder, 2014). According to FAO statistics, which classified Iraq Soil and pastures, especially in southern and middle Iraq as selenium-poor soils with a content of less than $0.3 \mathrm{mg}$ (FAO, 


\section{Dhari \&Kassim / Basrah J. Agric. Sci., 32 (2): 125-135, 2019}

2010). The body needs selenium in small quantities and excessive amounts may cause poisoning, and has several vital functions, including its effect on thyroid hormone, improve the performance of muscles and prevent the formation of heavy metals and make them harmless to the body of the animal (Novoselec et al., 2017). As well as improve the daily increase in weight and weight of lambs at birth (Gabryszuk \& Klewiec, 2002).

Selenium deficiency leads to several economic problems, the most important of which are lack of immunity, low of growth and fertility, abortions, low birth rates and low milk production (Farrag et al., 2017). Vitamin E preserves the secondary cellular membranes of peroxide and inhibits the oxidation of fat (phospholipids) in the main cellular membranes by reducing the formation of hydrogen peroxide and thus protects the cell membrane from oxidative stress (McDowell, 2008). It is considered an effective nutrient to improve fertility and fertility properties (Kassim, 2017) and prevent many reproductive disorders and its impact on the reproductive performance of ewes (Liu et al., 2014).

Al-Sa'agh \& Al-Rawi (2012) noted that vitamin $\mathrm{E}$ improves semen quality and male gametes. Selenium works in conjunction with vitamin $\mathrm{E}$ as antioxidants and strengthens the body's immune system (Shi et al., 2018). They also co-perform the function of protecting cell walls and cellular structures from oxidation and lack of either or both causes stiff lamb diseases and poor growth in sheep (Abdel Nasser, 2011). Their addition to sheep and goat nutrition improved metabolic criteria, growth, health and increased production (Soliman et al., 2012). The integrated relationship between mineral elements and vitamins significantly contributes to reducing or doubling the risk of metabolic disease in sheep. They perform complementary roles in the mechanical resistance of antioxidants and correct the results of oxidative stress (Masters, 2018).

The aim of this study is to investigate the effect of selenium and vitamin $E$ supplementation on Awassi male lambs after weaning on growth rates, daily weight gain, dry matter intake and levels of some metabolic hormones such as thyroxin, insulin and growth hormone.

\section{Materials \& Methods}

The experiment was conducted in a private farm of commercial sheep within the district of Muwafaqia, Wasit province. The field trial lasted from 1/10/2018 until 15/1/2019.

\section{Experimental animal and diet}

Sixteen Awassi male lambs were randomly selected from a local market with an average age of about 3.5-4 months and average weight $24.375 \pm 1.300 \mathrm{~kg}$. The study lasted 105 days. Lambs were housed in cages of $(3 \times 2 \mathrm{~m})$ with one cage per group (4 groups, 4 lambs each). Cages were inside a hald-shaded barn and a sandy floor and each cage are supplied with plastic receptacles for water and food. Lambs were underwent to veterinary care by following a preventive program that included FMD, Baghdad fever, intestinal and blood poisoning, sheep pox and internal and external worms. Then, at the beginning of the experiment, all lambs fed the same basal concentrate diet (Table 1) to meet the nutritional requirements of sheep according (NRC, 1985). The selenium amounts with purity $99 \%$ produced by MERCK/Germany and vitamin $\mathrm{E}$ with purity $98 \%$ of the company's HIMEDIA/India were mixed with $100 \mathrm{~g}$ of basal diet feed mixture by continuous stirring and gradual addition of concentrate to complete the homogeneity. The 


\section{Dhari \&Kassim / Basrah J. Agric. Sci., 32 (2): 125-135, 2019}

lambs were fed on diets once a day at $7 \mathrm{AM}$ according to the prescribed treatments in the study, concentrate ration were adjusted on the basis of $2 \%$ of the achieved weight body weekly. The remaining feed from the previous day is collected and weighed separately for each group before the morning meal. First group, Control (C): basal without any additives. Second group, $(\mathrm{Se})$ : basal $+0.4 \mathrm{mg}$ of selenium. Third group, (Vit. E): basal + $100 \mathrm{mg}$ of vitamin $\mathrm{E}$ and Fourth group, $(\mathrm{Se}+$ Vit. E): basal + $0.4 \mathrm{mg}$ of selenium $+100 \mathrm{mg}$ of vitamin E per kg dry matter, respectively. The live weight of the lambs was calculated by a field balance of $150 \mathrm{~kg}$, Daily weight gain and feed intake were calculated according to the following equations:

$$
\text { Daily weight gain }(\mathrm{g})=\frac{\text { weight achieved }- \text { previous weight }}{\text { time period }}
$$

Daily weight gain $(\mathrm{g})=$ Processed Feed $(\mathrm{g})-$ Residual Feed $(\mathrm{g}) \times \%$ D. M of concentrate

The Metabolic energy was calculated according to the Scottish Ministry of Agriculture equation (MAFF, 1975):

$$
\text { Metabolic energy } \frac{\mathrm{MJ}}{\mathrm{kg}} \text { Dry matter }=
$$

$0.012 \times$ Crude protein $+0.031 \times$ Ether extract $+0.005 \times$ Raw fiber $+0.014 \times$ Soluble carbohydrates.

Table (1): Components and percentages of the basal diet used in Experiment(On DM Basis $\%)^{*}$

\begin{tabular}{cc}
\hline Items & Percentage \\
\hline Barley & 50 \\
\hline Wheat bran & 35 \\
\hline Soybean meal & 5 \\
\hline Yellow corn & 9 \\
\hline Dinerals mixture without selenium $* *$ & 1 \\
\hline Dry Matter \% & 90.79 \\
\hline Crude protein $\%$ & 14 \\
\hline DM Metabolic Energy Mj/kg & 4901 \\
\hline NDF \%*** & 32.70 \\
\hline ADF $\% * * *$ & 8.56 \\
\hline
\end{tabular}

*( NRC, 1985).

** Mineral mixture contained Co as CoSO4, I as CoI2, Fe as FeSO4, Mn as MnO, Zn as ZnSO4, Mg as MgO., *** (Ibrahim \& Hassan, 2015).

\section{Collection of blood samples and laboratory analysis}

Blood samples were withdrawn from the jugular vein after shaving the wool in this area, cleaned and sterilized with ethyl alcohol by sterile medical $10 \mathrm{ml}$ syringe, $8 \mathrm{ml}$ placed in clean and sterile plastic tubes (GEL-Tube) and leave for 2 hours under room temperature $25^{\circ} \mathrm{C}$ to complete the process of coagulation. Then after the samples were collected, it was transported through a cooled container and placed in centrifugation at a speed of 3000 rounds per min for 15 minutes to separate the 


\section{Dhari \&Kassim / Basrah J. Agric. Sci., 32 (2): 125-135, 2019}

serum from other blood components, which is kept in airtight tubes under temperature $-20^{\circ}$ $\mathrm{C}$ in frozen until the implementation of hormonal tests (Kitchalong et al., 1995). Concentrations of thyroxin (T4) (ng. $\mathrm{ml}^{-1}$ ) were measured using the Afias-6 device according to the instructions of manufactured company kit (Boditech, Korea). The insulin hormone $\left(\mu \mathrm{U} \cdot \mathrm{ml}^{-1}\right)$ was measured using a pipette $50 \mu 1$ of insulin standards to microvessel dishes containing samples control with $100 \mu \mathrm{l}$ of the insulin enzyme detector and circular stirring 20-30 seconds for mixing and cover the dishes and incubate it for 60 minutes at room temperature and remove fluid from all vessels and washed 3 times with $350 \mu \mathrm{l}$ distilled water and add $100 \mu \mathrm{l}$ of substrate solution tetra methyl benzidine (TMB), incubated for 15 minutes at room temperature, add $50 \mu$ of stop solution sulfuric acid to all vessels, gently move to mix the solution and then read the absorbance with ELISA at wavelength 450 Nanometer within 15 minutes after adding stop solution. According to the company's instructions (Monobind/USA) which processed several analysis kits, the growth hormone (ng. $\mathrm{ml}^{-1}$ ) was measured using a $50 \mu 1$ pipette of growth hormone standards to micro-vessel dishes containing samples of treatments and control serums, add $100 \mu \mathrm{l}$ of HG enzyme, incubated for 30 minutes at room temperature, removed liquid of all vessels and washed 3 times with $350 \mu$ distilled water, add $100 \mu$ of substrate solution (TMB), incubate for 10 minutes at room temperature, add $50 \mu$ of stop solution to all the vessels, move gently to mix the solution and then read the adsorption with ELISA at wavelength 450 nanometers within 15 minutes after adding stop solution.

\section{Statistical analysis}

The data were statistically analyzed using the Completely Randomized Design (CRD). The significant differences between the means were determined by the $\mathrm{P}<0.05$ levels of significance. The obtained data were analyzed statistically using the SPSS (2013).

The model was as follows: $\mathrm{Yij}=\mu+\mathrm{Ti} .+$ eij. Where:

Yij : The observation of the treatment with selenium or vitamin $\mathrm{E}$.

$\mu$ : Common mean.

Ti..: The effect of the treatment.

eij.: The experimental error, randomly and naturally distributed on all observations.

\section{Results}

\section{Live body weights, Average daily gain and dry matter intake}

Live body weights of selenium and the combination of selenium + vitamin $\mathrm{E}$ treatment were significantly ( $\mathrm{p}<0.05$ ) higher 42.20 and $41.75 \mathrm{~kg}$, respectively than those of vitamin treatment and control group 36.60 and $39.00 \mathrm{~kg}$, respectively, While the control group showed significantly higher live body weight compared to vitamin treatment. Average daily gain of lambs during the study period of selenium and the combination of selenium + vitamin $E$ treatment were significantly higher ( $\mathrm{p}<0.05) 195 \mathrm{~g}$ and 191 $\mathrm{g}$ respectively, than those vitamin treatment and control group $139 \mathrm{~g}$ and $161 \mathrm{~g}$, respectively. While the control group recorded significantly higher growth rate than that of vitamin treatment. The treatment of selenium and the combination of selenium + vitamin $E$ treatment achieved the highest ( $p<0.05$ ) weight gain at 30 days from the beginning of the experiment $246 \mathrm{~g}$ and 250 $\mathrm{g}$, respectively. However, the treatment of selenium and the combination of selenium + vitamin E treatment improved Statistically 0.848 and $0.821 \mathrm{~kg}$, respectively, compared 


\section{Dhari \&Kassim / Basrah J. Agric. Sci., 32 (2): 125-135, 2019}

with vitamin treatment and control group 0.785 and $0.798 \mathrm{~kg}$, respectively (Table 2).

\section{Thyroxin hormone (T4)}

Overall mean of thyroxin concentration 18.20 ng.ml ${ }^{-1}$ in lambs' serum of the combination of selenium + vitamin $E$ treatment during the study period was significantly $(\mathrm{P}<0.05)$ higher than those of in selenium and vitamin treatments which recorded 14.60 and $12.00 \quad$ ng. $\mathrm{ml}^{-1}$ respectively. However, this difference was not significant in comparison with the control group $18.50 \mathrm{ng} \cdot \mathrm{ml}^{-1}$ (Table 3). The highest concentration of the hormone was recorded by the treatment of the combination of selenium + vitamin $\mathrm{E}$ in the third month of the experiment of $21.80 \mathrm{ng} \cdot \mathrm{ml}^{-1}$.

\section{Insulin hormone}

Overall mean of insulin concentrations have not recorded significant differences among treatments throughout the study. However, in the first month of study the combination of selenium + vitamin E treatment showed significantly higher $(\mathrm{p}<0.05) 40.874 \mu \mathrm{U} . \mathrm{ml}$ 1 compared with the other studied treatments
(Table 4). No significant differences were observed between the treatments during the second month of the trial. However, insulin concentration increased significantly (p $<0.05$ ) in selenium and vitamin treatments at the third month of the experiment.

\section{Growth hormone}

Overall mean of growth hormone concentration of selenium treatment 9.279 ng.ml-1increased ( $\mathrm{p}<0.05)$ compared to vitamin treatment and control group 8.485 and 8.393 ng.ml-1, respectively, but this significant difference was not present compared the combination of selenium + vitamin E 8.798 ng.ml $^{-1}$ (Table 5). Both combination of selenium + vitamin $\mathrm{E}$ and vitamin $\mathrm{E}$ treatments showed significantly ( $\mathrm{p}$ $<0.05)$ and mathematical differences respectively compared to the control group. No significant differences were observed between the treatments during the second month of the trial. The highest level of hormone concentration was achieved by selenium treatment in the third month of the experiment $9.577 \mathrm{ng} \cdot \mathrm{ml}^{-1}$.

Table (2): The effect of supplemental selenium with or without vitamin $E$ to the diets of Awassi male lambs on growth rates, average daily gain and dry matter intake. (Mean \pm standard error).

\begin{tabular}{ccccccc}
\hline $\begin{array}{l}\text { Parameters } \\
\text { / }\end{array}$ & $\begin{array}{c}\text { Initial body } \\
\text { weight }(\mathrm{kg})\end{array}$ & $\begin{array}{c}\text { Body weight } \\
(\mathrm{kg}) \text { at } 30 \\
\text { days }\end{array}$ & $\begin{array}{c}\text { Body weight } \\
(\mathrm{kg}) \text { at } 60 \\
\text { days }\end{array}$ & $\begin{array}{c}\text { Body weight } \\
(\mathrm{kg}) \text { at } 90 \\
\text { days }\end{array}$ & $\begin{array}{c}\text { Average } \\
\text { daily gain } \\
(\mathrm{g} / \mathrm{lamb} / \mathrm{day})\end{array}$ & $\begin{array}{c}\text { Dry matter } \\
\text { ntake } \\
(\mathrm{kg} / \mathrm{lamb} / \mathrm{day})\end{array}$ \\
\hline Control & $24.40 \pm 1.25 \mathrm{a}$ & $29.10 \pm 1.22 \mathrm{~b}$ & $33.50 \pm 0.64 \mathrm{~b}$ & $39.00 \pm 0.64 \mathrm{~b}$ & $161 \pm 8.61 \mathrm{~b}$ & 0.798 \\
\hline Se & $24.60 \pm 1.29 \mathrm{a}$ & $32.00 \pm 1.58 \mathrm{a}$ & $37.10 \pm 1.63 \mathrm{a}$ & $42.20 \pm 1.70 \mathrm{a}$ & $195 \pm 8.53 \mathrm{a}$ & 0.848 \\
\hline Vit. E & $24.00 \pm 1.51 \mathrm{a}$ & $28.70 \pm 1.45 \mathrm{~b}$ & $34.00 \pm 1.42 \mathrm{~b}$ & $36.60 \pm 1.24 \mathrm{c}$ & $139 \pm 4.98 \mathrm{c}$ & 0.785 \\
\hline Se+ Vit. E & $24.50 \pm 1.14 \mathrm{a}$ & $32.00 \pm 1.22 \mathrm{a}$ & $36.50 \pm 1.19 \mathrm{a}$ & $41.75 \pm 1.37 \mathrm{a}$ & $191 \pm 2.38 \mathrm{a}$ & 0.821 \\
\hline
\end{tabular}

Means with different superscript in the same column differ significantly $(p<0.05)$. 
Dhari \&Kassim / Basrah J. Agric. Sci., 32 (2): 125-135, 2019

Table (3): The effect of supplemental selenium with or without vitamin $E$ to the diets of Awassi male lambs on thyroxin concentration (ng.ml-1) (Mean \pm standard error).

Parameters/ 30 days 60 days 90 days Overall mean

Treatments

\begin{tabular}{ccccc}
\hline Control & $18.2 \pm 1.036 \mathrm{a}$ & $16.2 \pm 0.336 \mathrm{ab}$ & $21.2 \pm 0.456 \mathrm{a}$ & $18.5 \pm 0.091 \mathrm{a}$ \\
\hline $\mathrm{Se}$ & $12.0 \pm 2.460 \mathrm{~b}$ & $18.7 \pm 1.149 \mathrm{a}$ & $16.3 \pm 1.099 \mathrm{~b}$ & $15.6 \pm 0.081 \mathrm{~b}$ \\
\hline Vit. E & $12.1 \pm 0.266 \mathrm{~b}$ & $11.8 \pm 0.266 \mathrm{~b}$ & $12.3 \pm 0.258 \mathrm{~b}$ & $12.0 \pm 0.258 \mathrm{~b}$ \\
\hline Se+ Vit. E & $12.9 \pm 0.448 \mathrm{~b}$ & $20.0 \pm 3.213 \mathrm{a}$ & $21.8 \pm 4.727 \mathrm{a}$ & $18.2 \pm 2.730 \mathrm{a}$ \\
\hline
\end{tabular}

Means with different superscript in the same column differ significantly $(p<0.05)$.

Table (4): The effect of supplemental selenium with or without vitamin $E$ to the diets of Awassi male lambs on Insulin concentration ( $\left.\mu \mathrm{U} \cdot \mathrm{ml}^{-1}{ }^{1}\right)$ (Mean \pm standard error).

\begin{tabular}{|c|c|c|c|c|}
\hline $\begin{array}{l}\text { parameters } \\
\text { / } \\
\text { Treatments }\end{array}$ & 30 days & 60 days & 90 days & Overall mean \\
\hline Control & $24.352 \pm 0.090 b$ & $41.705 \pm 6.180 \mathrm{a}$ & $20.201 \pm 3.000 \mathrm{~b}$ & $28.752 \pm 3.066 \mathrm{a}$ \\
\hline $\mathrm{Se}$ & $23.993 \pm 0.244 b$ & $31.882 \pm 2.483 \mathrm{a}$ & $38.228 \pm 3.119 \mathrm{a}$ & $31.367 \pm 1.944 \mathrm{a}$ \\
\hline Vit. E & $20.568 \pm 0.185 b$ & $37.470 \pm 1.015 \mathrm{a}$ & $39.976 \pm 1.117 \mathrm{a}$ & $32.671 \pm 0.649 \mathrm{a}$ \\
\hline $\mathrm{Se}+$ Vit. E & $40.874 \pm 6.019 \mathrm{a}$ & $40.705 \pm 4.334 \mathrm{a}$ & $20.352 \pm 2.182 b$ & $33.977 \pm 0.187 \mathrm{a}$ \\
\hline
\end{tabular}

Table (5): The effect of supplemental selenium with or without vitamin $E$ to the diets of A wassi male lambs on growth hormone concentration (ng.ml ${ }^{-1}$ ) (Mean \pm standard error).

\begin{tabular}{|c|c|}
\hline Parameters/ & 30 days \\
\hline
\end{tabular}

Treatments

\begin{tabular}{ccccc}
\hline Control & $8.336 \pm 0.111 \mathrm{~b}$ & $8.599 \pm 0.113 \mathrm{a}$ & $8.245 \pm 0.107 \mathrm{~b}$ & $8.393 \pm 0.072 \mathrm{c}$ \\
\hline Se & $9.460 \pm 0.264 \mathrm{a}$ & $8.801 \pm 0.216 \mathrm{a}$ & $9.577 \pm 0.177 \mathrm{a}$ & $9.279 \pm 0.112 \mathrm{a}$ \\
\hline Vit. E & $8.695 \pm 0.114 \mathrm{~b}$ & $8.412 \pm 0.139 \mathrm{a}$ & $8.350 \pm 0.216 \mathrm{~b}$ & $8.485 \pm 0.056 \mathrm{bc}$ \\
\hline Se+ Vit. E & $8.754 \pm 0.081 \mathrm{~b}$ & $8.762 \pm 0.160 \mathrm{a}$ & $8.880 \pm 0.042 \mathrm{a}$ & $8.798 \pm 0.149 \mathrm{ab}$ \\
\hline
\end{tabular}

Means with different superscript in the same column differ significantly $(\mathrm{p}<0.05)$.

\section{Discussion}

\section{Live body weights, Average daily gain and} dry matter intake

Increased of the final live body weight of selenium and the combination of selenium + vitamin $\mathrm{E}$ treatments may be due to the role of selenium in the growth and metabolism of bones compared to the other treatments (Cao etal., 2012). Vitamins and minerals also play a role in the synthesis and construction of enzymes related to metabolic processes which have a direct effect in improving animal growth (Willshire \& Payne, 2011) This is consistent with Das (2011) in his study about hybrid goats and Soliman et al. (2012) with his study of pregnant ewes and Ramadan et al. (2018) for pregnant goats. But it did not agree with the results of Mahboub et al. (2011) in his study of pregnant Egyptian goat breeds. Most likely the variation of the diet and form of feed additives, growth and 


\section{Dhari \&Kassim / Basrah J. Agric. Sci., 32 (2): 125-135, 2019}

physiological states it may explain the difference in the results of this study with other studies (Vignola et al., 2009). Improved of a daily gain for the lambs of the combination of selenium + vitamin $\mathrm{E}$ and selenium treatment may be due to the fact that these additives improved health status. Thus reflecting on the responses to levels of growth and productivity (Ali et al., 2004). On the other hand, vitamin $\mathrm{E}$ plays an essential role in building the membranes of fat cells in the muscle structure, which contributes to the growth of muscle mass of the body (Klein et al., 1983; Luseba, 2001). These findings are consistent with what observed by Alhidary et al. (2012) and Chauhan et al. (2016) in two experiment about the male lambs of Merino and the Australian male crossbreed respectively, But Maraba et al. (2018) found no differences in daily intakes. As the isolation of lambs in cages may be one of the most stressful conditions that lead to many behavioral and physiological effects such as social isolation, fear, furthermore, the difference between animals in sizes causes that the big one (Domain) consume more than the small and the weaker one did not eat enough when feed in groups, which may negatively effect on feed intake and growth (Bouissou et al., 2001; Fisher \& Matthews, 2001; Falowo et al., 2014; Chulayo \& Muchenje, 2015).

\section{Thyroxin hormone (T4)}

High concentration of thyroxin in the lambs' serum of the treatment of the combination of selenium + vitamin E may be due to the direct action of selenium and its ability to increase glucose metabolism (Mao \& Teng, 2013). As a component of the enzyme (peroxidase) responsible for the essential role of iodine oxidation and its conversion from the inorganic iodine (I-) to iodine (I) which is associated with tyrosine acid to form hormones ( $\mathrm{T} 3$ and $\mathrm{T} 4$ ), and increased response and activity of the thyroid gland (Todini, 2007). It is a vital and essential factor for the effectiveness of selenium enzymes (deiodinases) to convert thyroxin T4 (inactive form) to T3 (active form) (Hefnawy \& Tortora- Perez, 2010). This corresponds to the results of the male lambs of the strain Akkaraman in a study they conducted Naziroglu \& Cay (1998) and study of Rock et al. (2001) on crossbreeding pregnant ewe and El-Shahat \& Abdel Monem (2011) in his study of Egyptian ewes strain Baladi. The results differed with his findings Ziaei (2015) in a study which the goats used the mature Raieni strain. The cause may be due to differences in the physiological state of the animal and the increased stress which cause low performance of hormone (Vignola et al., 2009).

\section{Insulin hormone}

Concentrations of insulin in lambs serum in the current study did not affect. However, this result can be explained by the fact that insulin as the main hormone responsible for the regulation of glucose levels in the body, on the other hand, both selenium and vitamin $\mathrm{E}$ are play important role in the absorption of glucose and energy balance (Spears, 2011), so, naturally that needs more insulin secretion from the pancreas (Hefnawy \& Tortora-Perez, 2010). According to Debski et al. (2004) selenium has a role in activation the attachment between insulin hormone and it is receptors on the target cell and improving post-receptor signals. This supports their findings (Zahrazadeh et al., 2018) in their study of Dairy Holstein cows. The results of the current study differed from the results of a study for Dominguez-Vara et al. (2009). This discrepancy with the results of the study may be due to the nature of the 


\section{Dhari \&Kassim / Basrah J. Agric. Sci., 32 (2): 125-135, 2019}

selenium status and its proportion in the feed composition used.

\section{Growth hormone}

Response of growth hormone concentration to increase of selenium treatment. This may be due to the fact that thyroid hormones increase the levels of mRNA in the pituitary cells to secrete the hormone (Moav \& McKeown, 1992; Farchi-Pisanty et al., 1995), or role of selenium by raising the concentration of growth hormone through its associated with an increase in the activity of deiodination to convert thyroid hormone from T4 to T3 which is necessary to form the hormone naturally in the pituitary gland or to the activity of the thyroid gland which is selenium considered an essential part of the deiodinase enzyme that considered component of their necessary hormones for the secretion of the natural growth hormone of the pituitary gland to many mammal species (Valcavi et al., 1992; Muller et al., 1999), or that the apparent increase in the size of the frontal lobe of the pituitary gland and secretion of the hormone is associated with increase of selenium level (Muller et al., 1999).

\section{Conclusions}

The results showed that the addition $0.4 \mathrm{mg}$ of selenium with $100 \mathrm{mg}$ of vitamin $\mathrm{E} / \mathrm{kg}$ to lamb's diets significantly improved most of the production traits such as final body weight and daily weight gain, and proved effective improvement of some physiological traits by increasing concentrations of hormones related to dietary metabolism such as thyroxin (T4) and growth hormone.

\section{Acknowledgements}

The authors would like to thank the possessor of the commercial animal field to allow us to use his boxes during the experiment. Also, we are grateful to the workers in biochemical laboratory for their helping in biochemical tests.

Ethical approval: all applicable national and international guidelines for the care and use of animals were followed.

\section{References}

Abdel Nasser, I.M. (2011). Selenium and its role in humans and animals. Ass. J. Enviro. Stud., 35: 15-20.

Alhidary, I.A.; Shini, S.; Al Jassim, R.A.M. \& Gaughan, J.B. (2012). Effect of various doses of injected selenium on performance and physiological responses of sheep to heat load1. J. Anim. Sci., 90: 2988-2994.

Ali, A.; Morrical, D.G.; Hoffman, M.P. \& AlEssa, M.F. (2004). Evaluation of vitamin $E$ and selenium supplementation in late gestation on lamb survival and preweaning growth. J. Prod. Anim. Sci., 20(6): 506511.

Al-Sa'agh, M.N.R. \& Al-Rawi, S.T.J. (2012). Effect of using ginger (Zingiber officinale) and vitamin $\mathrm{E}$ in some of the reproductive characteristics of the Awassi male lambs. $11^{\text {th }}$ Sci. Conf. Fac. Vet. Med., Iraq, 2012: 134-141.

Argüello, A. (2011). Trends in goat research, a review. J. Appl. Anim. Res., 39(4): 429434.

Bouissou, M.F.; Boissy, A.; Le Neindre, P. \& Veissier, I. (2001). The Social Behavior of Cattle. 113-145. In: Keeling, L.J. \& Gonyou, H.W. (Eds.). Social Behavior in Farm Animals. CABI Publishing, Wallingford. 406pp

Cao, J.J.; Gregoire, B.R. \& Zeng, H. (2012). Selenium deficiency decreases the antioxidative capacity and is detrimental to 


\section{Dhari \&Kassim / Basrah J. Agric. Sci., 32 (2): 125-135, 2019}

bone microarchitecture in mice. J. Nutr., 142: 1526-1531.

Chauhan, S.S.; Ponnampalam, E.N.; Celi, P.; Hopkins, D.L.; Leury, B.J. \& Dunshea, F.R. (2016). High dietary vitamin $\mathrm{E}$ and selenium improves feed intake and weight gain of finisher lambs and maintains redox homeostasis under hot conditions. Small Rumin Res., 137:17-23.

Chulayo, A.Y. \& Muchenje, V. (2015). A balanced perspective on animal welfare for improved meat and meat products. S. Afr. J. Anim. Sci., 45: 452-469.

Das, T.K. (2011). Effect of vitamin $E$ supplementation on stress related genes, oxidative stress, immunity. and milk production in arsenic exposed goat. $\mathrm{Ph}$. D. Thesis. National Dairy Research Institute, Karnal, Haryana, India: 122.

Debski, B.; Zalewski, W.; Gralak, M.A. \& Kosla, T. (2004). Chromium-yeast supplementation of chicken broilers in an industrial farming system. J. Trace Elem. Med. Biol., 18: 47-51.

Dominguez-Vara, I.A.; González-Mũnoz, S.S.; Pinos-Rodríguez, J.M.; BórquezGastelum, J.L.; Bárcena-Gama, R.; Mendoza-Martínez, G.; Zapata, L.E. \& Landois-Palencia, L.L. (2009). Effects of feeding selenium-yeast and chromiumyeast to finishing lambs on growth, carcass characteristics, and blood hormones and metabolites. Anim. Feed Sci. Tecnol., 152: 42-49.

El-Shahat, K.H. \& Abdel Monem, U.M. (2011). Effects of dietary supplementation with vitamin $\mathrm{E}$ and /or selenium on metabolic and reproductive performance of Egyptian Baladi ewes under subtropical conditions. J. World Appl. Sci., 12(9): 1492-1499.
Falowo, A.B.; Fayemi, P.O. \& Muchenje, V. (2014). Natural antioxidants against lipidprotein oxidative deterioration in meat and meat products: a review. Food Res. Int., 64: 171-181.

FAO. (2010). Breeding strategies for sustainable management of animal genetic resources. Food and Agriculture Organization. Roma, Italy, FAO Animal Production and Health Guidelines Number 3, XVII -12.

Farchi-Pisanty, O.; Hackett, J.P.B. \& Moav, B. (1995). Regulation of fish growth hormone transcription. Mol. Mar. Biol. Biotechnol., 4: 215-223.

Farrag, B.; El-Hawy, A.; Sobhy, E. \& Moharram, F. (2017). Improving reproductive and productive efficiency of Barki sheep by using GnRH and selenium. J. World Vet., 7(4): 128-136.

Fisher, A. \& Matthews, L. (2001). The Social Behavior of Sheep. 211-245. In: Keeling, L., Gonyou, H. (Eds.). Social Behavior in Farm Animals. CABI Publishing, Wallingford: 406pp

Gabryszuk, M. \& Klewiec, J. (2002). Effect of injecting 2- and 3-year-old ewes with selenium and selenium-vitamin $\mathrm{E}$ on reproduction and rearing of lambs. Small Rumin. Res., 43: 127-132.

Hefnawy, A.E. \& Tortora-Perez, J.L. (2010). The importance of selenium and the effect of its deficiency in animal health. Small. Rumin. Res., 89: 185-192.

Ibrahim, S.S. \& Hassan, Sh.A. (2015). Effect of using feed blocks containing different nitrogen sources and with or without peaker yeast on blood characteristics of Awassi rams. J. Anbar. Vet. Sci., 8(1): 3749. 


\section{Dhari \&Kassim / Basrah J. Agric. Sci., 32 (2): 125-135, 2019}

Kassim, W.Y. (2017). The Effect of vitamin E and PMSG treatment during breeding season on some biochemical parameters and reproductive trails for two breeds of sheep. Basrah J. Agric. Sci., 30(2): 83-90.

Kitchalong, L.; Fernandez, J.M.; Bunting, L.D.; Southern, L.L. \& Bidner, T.D. (1995). Influence of chromium tripicolinate on glucose metabolism and nutrient partitioning in growing lambs. J. Anim. Sci., 73: 2694-2705.

Klein, A.H.; Reviczky, A.; Chou, P.; Padbury, J. \& Fisher, D.A. (1983). Development of brown adipose tissue thermogensis in the ovine fetus and newborn. Endocrinol., 112: 1662-1666.

Linder, S. (2014). Selenium in Swedish sheep production. M. Sc., Swedish Univ. Agric. Sci.: 32pp.

Liu, S.; Masters, D.; Ferguson, M. \& Thompson, A. (2014). Vitamin E status and reproduction in sheep: potential implications for Australian sheep production. J. Anim. Prod. Sci., 54(6): 694-714.

Luseba, D. (2001). The effect of selenium and chromium on stress level, growth performance, selected carcass characteristics and mineral status of feedlot cattle. Ph. D. Thesis. Fac. Vet. Sci., Univ. Pretoria. Onderstepoort,:193pp.

MAFF. (1975). Ministry of Agriculture and Fisheries/ Foot Dept. Agric. Fisher. Scotland: Energy allowances and feed systems for ruminants. Technical Bulletin, 33. 1- 79.

Mahboub, H.D.H.; Darwish, R.A.; Ramadan, S.G.; Helal, M.A. \& Gaafar, K.M. (2011). The effect of protected fat and seleniumvitamin $\mathrm{E}$ supplementation during late pregnancy on performance of local
Egyptian goat breeds and survival of their kids. $11^{\text {th }}$ Sci. Cong., Egyptian Soc. Cattle Dis., 5: 37-46.

Mao, J. \& Teng, W. (2013). The relationship between selenoprotein $\mathrm{P}$ and glucose metabolism in experimental studies. Nutrients, 5(6): 1937-1948.

Maraba, K.P.; Mlamboa, V.; Yusuf, A.O.; Marume, U. \& Hugo, A. (2018). Extra dietary vitamin E-selenium as a mitigation strategy against housing-induced stress in Dohne Merino lambs: Effect on growth performance, stress biomarkers, and meat quality. Small Rumin. Res., 160: 31-37.

Masters, D.G. (2018). Practical implications of mineral and vitamin imbalance in grazing sheep. J. Anim. Prod. Sci., 58(8): 1438-1450.

McDowell, L.R. (2008). Vitamins in Animal and Human Nutrition. John Wiley and Sons, $2^{\text {nd }}$ ed., Iowa State Univ. Press, Ames, I.A.: 673pp.

Moav, B. \& McKeown, B.A. (1992). Thyroid hormone increases transcription of growth hormone mRNA in rainbow trout pituitary. Horm. Metabol. Res., 24:.10-14.

Muller, E.E.; Locatelli, V. \& Cocchi, V.D. (1999). Neuroendocrine control of growth hormone secretion. Physiol. Rev., 79: 511607.

Naziroglu, M. \& Cay, M. (1998). Effects of selenium and vitamin $\mathrm{E}$ supplementation on concentrations of plasma thyroid hormones in lambs. J. Turk. Vet. Anim. Sci., 22: 157-160.

Novoselec, J.; Šperanda, M.; Klir, Ž.; Mioč, B.; Steiner, Z. \& Antunović, Z. (2017). Blood biochemical indicators and concentration of thyroid hormones in heavily pregnant and lactating ewes 


\section{Dhari \&Kassim / Basrah J. Agric. Sci., 32 (2): 125-135, 2019}

depending on selenium supplementation. J. Acta. Vet. Brno., 86: 353-363.

NRC. (1985). Nutrient Requirements of Sheep. 6th rev Ed. Natl. Acad. Press, Washington, D.C.: 3pp.

Ramadan, S.G.A.; Mahboub, H.D.H.; Helal, M.A.Y. \& Sallam, M.A. (2018). Effect of vitamin $\mathrm{E}$ and selenium on the performance and productivity of goats. Int. J. Chem. Bio. Sci., 4(2): 16-22.

Rock, M.J.; Kincaid, R.L. \& Carstens, G.E. (2001). Effects of prenatal source level of dietary selenium on passive immunity and thermo metabolism of newborn lambs. Small Rumin. Res., 40: 129-138.

Shi, L.; Ren, Y.; Zhanga, C.; Yuea, W. \& Lei, F. (2018). Effects of organic selenium (Seenriched yeast) supplementation in gestation diet on antioxidant status, hormone profile and haematobiochemical parameters in Taihang black goats. J. Anim. Feed Sci. Techno., 238: 57-65.

Soliman, E.B.; Ibrahim, A.K. \& Kassab, A.Y. (2012). The combined effect of vitamin $E$ and selenium on some of the productive and physiological characteristics of ewes and their pregnancy during lactation. J. Egyptian Sheep Goat Sci., 7(2): 31- 42.

Spears, J.W. (2011). Role of mineral and vitamin status on the health of cows and calves. WCDS Adv. Dairy Technol., 23: 287-297.

SPSS. (2013). Statistical Package for the Social Studies, Advanced Statistics,
Version 10.0 for Windows, SPSS Inc., Chicago.

Todini, L. (2007). Thyroid hormones in small ruminants: Effects of endogenous, environmental and nutritional factors. Animal, 7: 997-1008.

Valcavi, R., Zini, M. \& Portioli, I. (1992). Thyroid hormones and growth hormone secretion. J. Endocrinol. Invest., 15: 313330.

Vignola, G.; Lambertini, L.; Mazzone, G.; Giammarco, M.; Tassinari, M.; Martelli, G. \& Bertin, G. (2009). Effects of selenium source and level of supplementation on the performance and meat quality of lambs. Meat Sci., 81: 678685.

Willshire, J.A. \& Payne, J.H. (2011). Selenium and vitamin E in dairy cows: A review. Cattle Pract., 19: 22-30.

Zahrazadeh, M.; Riasi, A.; Farhangfar, H. \& Mahyari, S.A. (2018). Effects of close-up body condition score and selenium-vitamin E injection on lactation performance, blood metabolites, and oxidative status in highproducing dairy cows. J. Dairy Sci., 10 (11): 10495-10504.

Ziaei, N. (2015). Effect of selenium and vitamin $\mathrm{E}$ supplementation on reproductive indices and biochemical metabolites in Raieni goats. J. Appl. Anim. Res., 43(4): 426-430. 